\title{
Prototype Mini Crane Pemindah Barang Berbasis Sistem Otomasi
}

\author{
Aldi Alamsyah ${ }^{1}$, Hendi Purnata ${ }^{2}$, Muhammad Yusuf ${ }^{3}$ \\ 1,2,3 Program Studi Teknik Elektronika, \\ Jurusan Teknik Elektro, Politeknik Negeri Cilacap, Indonesia \\ 19alamsyahdi85@gmail.com, ${ }^{2}$ hendipurnata@pnc.ac.id, ${ }^{3}$ yusuf@pnc.ac.id
}

\begin{abstract}
Crane is a tool used to make it easier to move and lift an item. This research aims to create a mini crane system for optimizing the movement of goods based on industrial automation that utilizes PLC (programmable logic controller) as the controller and Pneumatik s as the actuator. This system uses a Mitsubishi PLC as the main controller. PLC works based on the input obtained from the selector switch to select a manual or automatic work system. There is a push button as a start and stop button, a limit switch as a limiter for the movement of the $\mathrm{X}$ and $\mathrm{Y}$ axes of the Rodless Cylinder to move items, proximity sensors to detect the presence of items to be moved and those that have been moved. In the results of this study, the sensor used to detect the type of workpiece material uses an inductive proximity sensor. In one crane process takes a maximum of 15.37 seconds. The maximum weight that a vacuum can suck at a pressure of $3 \mathrm{bar}$ is $650 \mathrm{~g}$, at a pressure of $4 \mathrm{bar}$ it is $950 \mathrm{~g}$, and at a pressure of $6 \mathrm{bar}$ it is $1059 \mathrm{~g}$.
\end{abstract}

Keywords - Mini Crane, PLC Mitsubishi, Pneumatik, Proximity, Automation industry

Abstrak-Crane merupakan alat yang digunakan untuk mempermudah dalam memindahkan dan mengangkat suatu barang. Peneltian ini bertujuan untuk membuat sistem mini crane untuk optimalisasi pemindahan barang berbasis otomasi industri yang memanfaatkan PLC (programmable logic controller) sebagai kontroler dan pneumatik sebagai aktuatornya. Sistem ini menggunakan PLC Mitsubishi sebagai pengendali utama. PLC bekerja berdasarkan masukan yang diperoleh dari selector switch untuk memilih sistem kerja manual atau otomatis. Terdapat push button sebagai tombol start dan stop, limit switch sebagai pembatas gerak sumbu $X$ dan Y dari Rodless Cylinder untuk memindahkan barang, proximity sensor untuk mendeteksi keberadaan dari barang yang akan dipindahkan dan yang telah dipindahkan. Pada hasil penelitian ini sensor yang digunakan untuk mendeteksi jenis material benda kerja menggunakan sensor proximity inductive. Dalam satu proses crane membutuhkan waktu maksimal 15,37 detik. Berat maksimal yang dapat dihisap vacuum pada tekanan 3 bar adalah 650g, pada tekanan 4 bar adalah 950g, dan pada tekanan 6 bar adalah 1059g.

Kata kunci-Mini Crane, PLC Mitsubishi, Pneumatik, Proximity, Otomasi Industri

\section{PENDAHULUAN}

Teknologi otomatisasi akan mengembangkan kualitas dan kuantitas hasil produksi dengan mempergunakan mesin-mesin di dunia industri saat ini. Pneumatik adalah sebuah cabang ilmu teknik yang mempelajari udara bertekanan, baik gerakan, kondisi, atau pemanfaatannya. Pneumatik memanfaatkan udara bertekanan dari kompresor yang sebagai komponen utama guna untuk menjalankan sistem pneumatiknya [1-2]. Overhead travelling crane adalah perangkat penting, banyak digunakan di industri, pabrik baja, galangan kapal, rel kereta api dll. Crane merupakan alat yang digunakan untuk mempermudah dalam memindahkan dan mengangkat suatu barang. Saat ini penggunaan crane sebagai material handling sangat penting maanfaatnya. Terbukti dengan banyaknya jenis-jenis crane yang digunakan dalam mengangkat suatu beban yang berat. Namun pada penggunaannya, sebagian crane tidak bekerja secara otomatis, harus menggunakan operator untuk mengendalikannya [3].

Penelitian [4] dibuat alat perancangan dan implementasi PLC hot standby dan SCADA (supervisory control and data acquisition) pada miniatur alat pemindah barang, alat ini dikendalikan oleh PLC dan prosesnya dapat dilihat menggunakan SCADA yang mana pengawasan dapat dilakukan melalui PC tanpa harus kelapangan. Crane pada alat ini dapat dikendalikan melalui PC dan joystick dengan komunikasi wireless. Didalam PC terdapat software SCADA
Vijeo Citect yang dapat memonitor kerja sistem dan mengendalikan sistem secara otomatis dengan cara menentukan titik koordinat dan level ketinggian barang yang diinginkan.

Penelitian [5] membuat Rancang Bangun Media Praktikum Sistem Pneumatik Berbasis PLC, alat ini menggunakan udara bertekanan dari kompresor dialirkan ke manifold pneumatik dan diteruskan ke katup solenoid $5 / 2$ jalan. Kekurangan pada sistem pemindahan barang yang masih manual belum menggunakan kontroler. Penelitian [6] membuat Perancangan Lengan Robot pneumatik Pemindah Plat Menggunakan PLC. Perancangan sistem kontrol berbasis PLC pada penggunaan cylinder pneumatik sebagai final control element suatu lengan robot. Pada penelitian [7] membuat Sistem Pengepakan Botol Minuman Kemasan Berbasis Programmable Logic Controller, dengan adanya perancangan dan pembuatan mesin yang dimaksud dapat dilihat bagaimana cara merancang perangkat keras maupun perangkat lunak yang baik untuk menciptakan suatu alat pengepakan yang bisa digunakan oleh pabrik-pabrik air minum kemasan yang ada.

Penelitian [8] mengungkapkan bahwa salah satu mengatasi permasalahan yaitu dengan menggunakan PLC dan berbasis SCADA. PLC yang digunakan pada penelitian ini menggunkan PLC Omron CJ1M dan hanya dapat memindahkan benda sebesar 300 gram. 
Jadi terlihat dari beberapa penelitian terdapat kekurangan maupun kelebihan. Pada penelitian ini bertujuan untuk membuat sistem mini crane untuk optimalisasi pemindahan barang berbasis otomasi industri yang memanfaatkan PLC sebagai kontroler dan Pneumatik sebagai aktuatornya.

\section{METODE}

Metode penelitian yang dilakukan pada pembuatan jurnal ini adalah melakukan beberapa tahap mulai dari studi literatur, perencanaan hardware, perencanaan software sampai ke proses pembuatan hingga implementasi dari sistem yang telah dibuat.

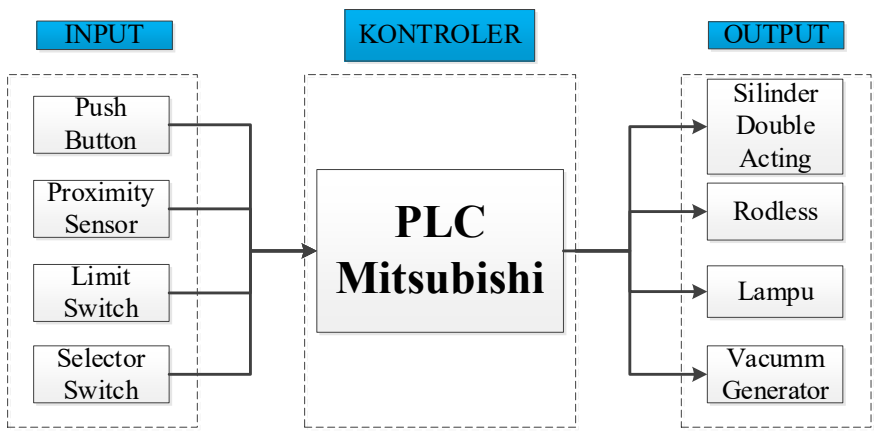

Gambar 1. Diagram Blok Sistem

Pada Gambar 1. dijelaskan bahwa sistem menggunakan satu mikrokontroler yaitu PLC Mitsubishi sebagai pengendali utama. PLC bekerja berdasarkan masukan yang diperoleh dari selector switch untuk memilih sistem kerja manual atau otomatis. Terdapat push button sebagai tombol start dan stop, limit switch sebagai pembatas gerak sumbu X dan Y dari Rodless Cylinder untuk memindahkan barang, proximity sensor untuk mendeteksi keberadaan dari barang yang akan dipindahkan dan yang telah dipindahkan.

Gambar 2. menjelaskan flowchart yaitu saat kontroller dinyalakan dan push button start ditekan, akan melakukan pembacaan apakah ada benda untuk dipindahkan dan apakah terdeteksi ada benda dan tempat 1 tidak mendeteksi adanya benda pada posisi pertama, maka cylinder turun lalu vacuum menghisap benda dan kemudian rodless 1 bergerak sumbu Y sampai menyentuh limit switch 1 cylinder turun dan vacuum melepaskan benda pada posisi 1 delay 5 detik cylinder naik kemudian rodless 1 bergerak kembali ke posisi awal. Ketika tempat 1 mendeteksi adanya benda, lalu tempat 2 mendeteksi tidak ada benda pada posisi 2 maka cylinder turun diposisi awal dan vacuum menghisap benda yang terdeteksi di posisi awal untuk dipindahkan setelah itu rodless 2 bergerak sumbu X ke arah posisi 2 sampai menyentuh limit switch 2 kemudian cylinder turun vacuum melepaskan benda delay 5 detik cylinder naik kembali dan rodless bergerak lagi ke posisi awal. Setelah tempat 1 dan 2 mendeteksi ada benda maka selanjutnya tempat 3 mendeteksi, jika tidak ada benda pada posisi 3 maka cylinder turun pada posisi awal dan vacuum menghisap benda kemudian rodless 2 bergerak sumbu X sampai menyentuh limit switch 2 setelah itu rodles 1 bergerak sumbu Y ke arah posisi 3 sampai menyentuh limit switch 1 kemudian cylinder turun dan vacuum melepas benda delay 5 detik lalu silider naik dan rodless kembali ke posisi awal dan ketika ada pembacaan benda pada posisi awal namun tempat 1, 2, dan 3 telah terisi semua, cylinder tidak akan turun untuk memindahkan benda dan proses selesai.

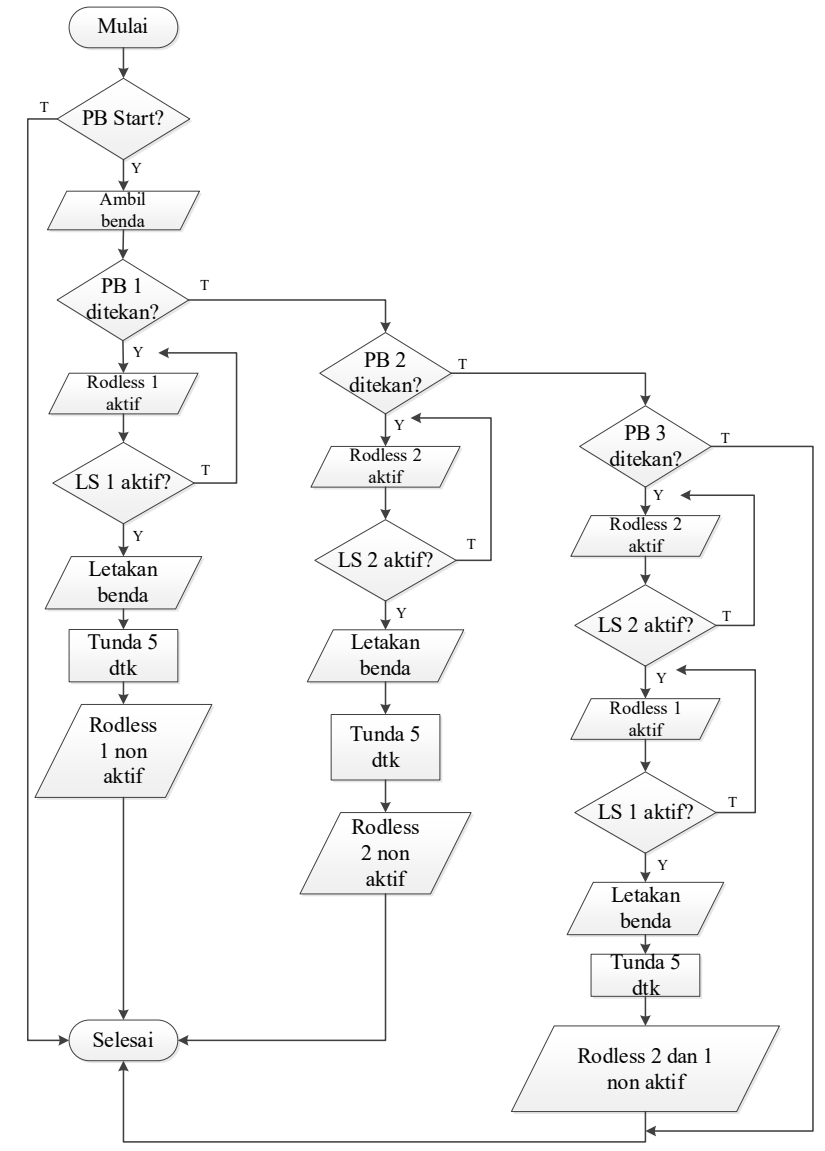

Gambar 2. Flowchart Sistem

Tujuan dari flowchart sistem ini digunakan sebagai alternatif ketika terjadi error pada sensor pembacaan tempat 1, 2, dan 3 pada otomatis sistem. Maka manual sistem ini yang dikendalikan oleh operator dengan hanya menekan tombol start untuk mengambil benda dan dipindahkan dengan menekan PB 1 untuk memindahkan ke tempat 1, PB 2 untuk memindahkan ke tempat 2, dan PB 3 untuk memindahkan ke tempat 3. Dan pemindahan ini hanya dilakukan untuk 1 benda dan tidak bisa untuk melakukan penumpukan pada benda berikutnya.

TABEL I

\begin{tabular}{ccc} 
& & KETERANGAN FLOWCHART \\
\hline No & Nama & Keterangan \\
\hline 1 & PB Start & Tombol untuk memulai kerja sistem \\
2 & PB 1 & Tombol manual tempat 1 \\
3 & PB 2 & Tombol manual tempat 2 \\
4 & PB 3 & Tombol manual tempat 3 \\
5 & Rodless 1 & Bergeser sumbu Y \\
6 & Rodless 2 & Bergeser sumbu X \\
7 & LS 1 & Limit switch sumbu Y \\
8 & LS 2 & Limit switch sumbu X \\
\hline
\end{tabular}

Gambar 3. merupakan diagram Langkah proses Mini Crane terjadi ketika Silinder A maju mencapai titik maksimal dengan timer yang ditentukan, maka vacuum D menghisap 
benda kerja. Lalu silinder A mundur sampai mencapai titik minimal, setelah itu rodless B maju mencapai titik maksimal

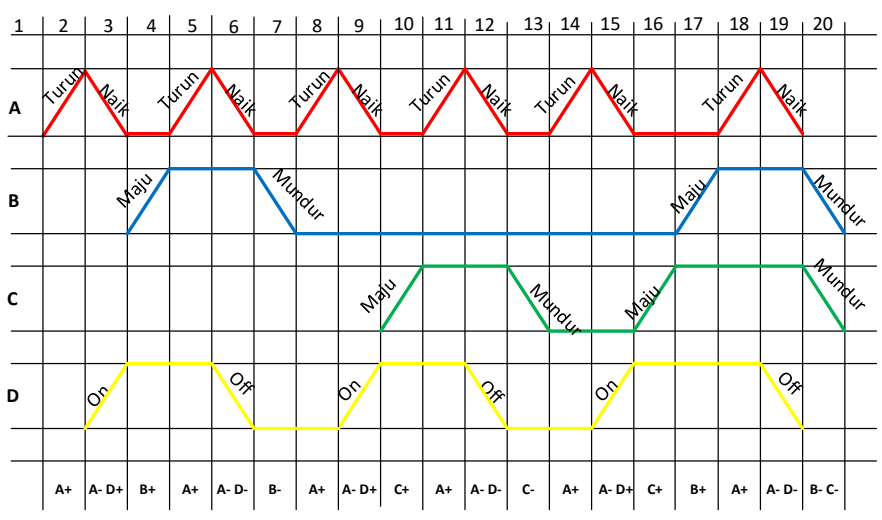

Gambar 3. Diagram Langkah Sistem

hingga menekan limit switch 1. Lalu Silinder A maju mencapai titik maksimal dengan timer yang ditentukan, maka vacuum $\mathrm{D}$ melepas benda kerja kemudian silinder $\mathrm{A}$ dan rodless $\mathrm{B}$ kembali ke titik minimalnya. Silinder A maju mencapai titik maksimal dengan timer yang ditentukan, maka vacuum $\mathrm{D}$ menghisap benda kerja. Lalu silinder A mundur sampai mencapai titik minimal, setelah itu rodless $\mathrm{C}$ maju mencapai titik maksimal hingga menekan limit switch 2. Lalu Silinder A maju mencapai titik maksimal dengan timer yang ditentukan, maka vacuum D melepas benda kerja kemudian silinder A dan

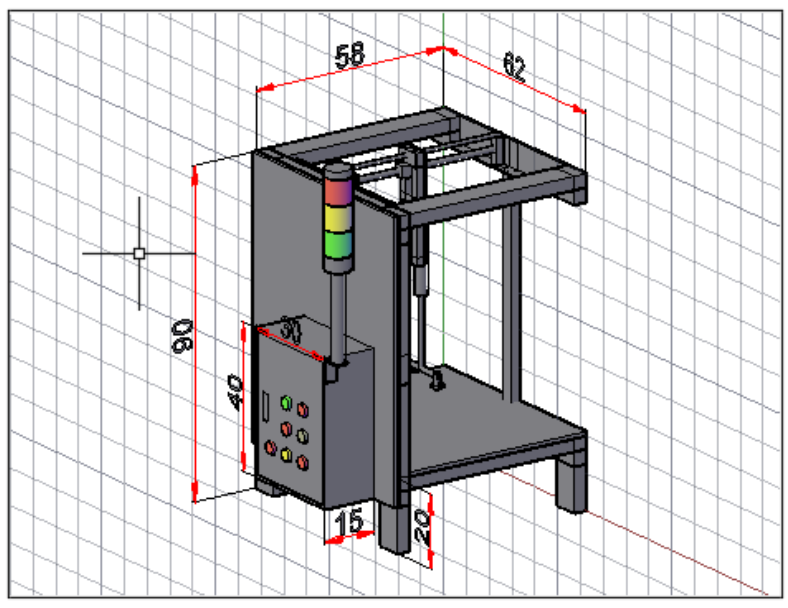

Gambar 4 Desain Mekanik

rodless $\mathrm{C}$ kembali ke titik minimalnya. Silinder A maju mencapai titik maksimal dengan timer yang ditentukan, maka vacuum D menghisap benda kerja. Lalu silinder A mundur sampai mencapai titik minimal, setelah itu rodless $\mathrm{C}$ maju mencapai titik maksimal hingga menekan limit switch 2. Kemudian rodless $\mathrm{B}$ maju mencapai titik maksimal hingga menekan limit switch 1. Lalu Silinder A maju mencapai titik maksimal dengan timer yang ditentukan, maka vacuum $\mathrm{D}$ melepas benda kerja kemudian silinder $\mathrm{A}$, rodless $\mathrm{B}$ dan rodless $\mathrm{C}$ kembali ke titik minimalnya dan proses selesai.
Gambar 4. Merupakan desain tampilan desain mekanik menggunakan software Autocad 2017 terdapat beberapa bagian yang harus dibuat untuk dapat bekerja dengan baik. desain Rancang Bangun Sistem Mini Crane Pemindah Barang Berbasis PLC Pneumatik lengkap dengan ukurannya, kontrol sistem berada di dalam box panel. Terdapat tiga lampu sebagai indikator kerja dari sistem mini crane pemindah barang

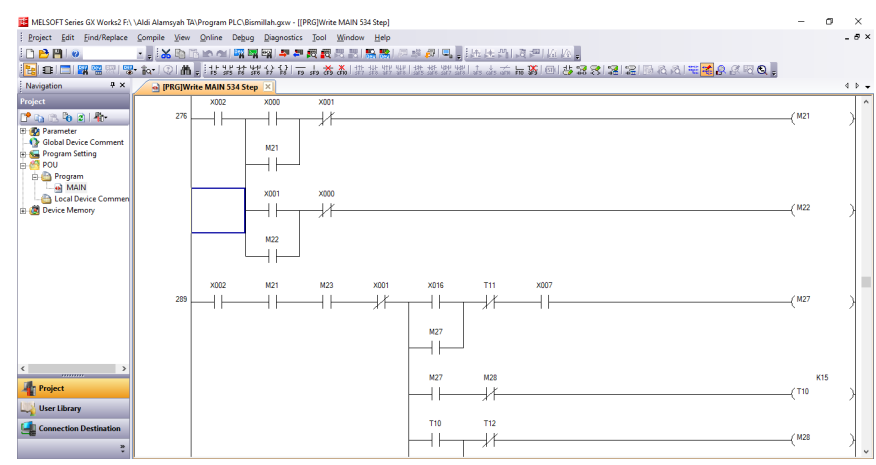

Gambar 5 Perancangan PLC Mitsubishi

Perangkat PLC yang digunakan menggunakan Mitsubishi diprogram dengan software GX Works. PLC merupakan perangkat utama kontroler untuk mengendalikan atau memerintahkan seperti sensor proximity, memerintahkan Pneumatik agar cylinder dapar bergerak. Gambar 8. Dibawah ini meruapak perancangan pada software GX Works.

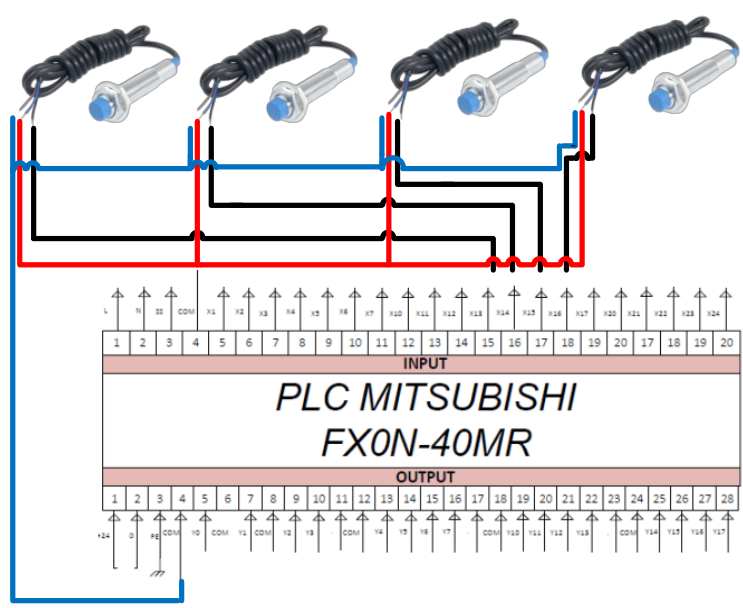

Gambar 6 Sensor Proximity

Implementasi sistem dirancangn menggunakan desain mekanik dan elektrik, elektrik menggunakan proximity dan pushbutton seperti Gambar 6. dan Gambar 7. Sensor proximity menggunakan jenis inductive atau sensor jarak elektronik yang mendeteksi benda logam tanpa menyentuhnya. Pada penelitian ini menggunakan 4 (empat) buah sensor proximity inductive.

Gambar 8. Merupakan perancangan rangkaian pneumatik digunakan untuk gerak komponen-komponen mini crane yang menggunakan udara. Komponen yang digunakan untuk mengatur gerak mini crane adalah valve. 


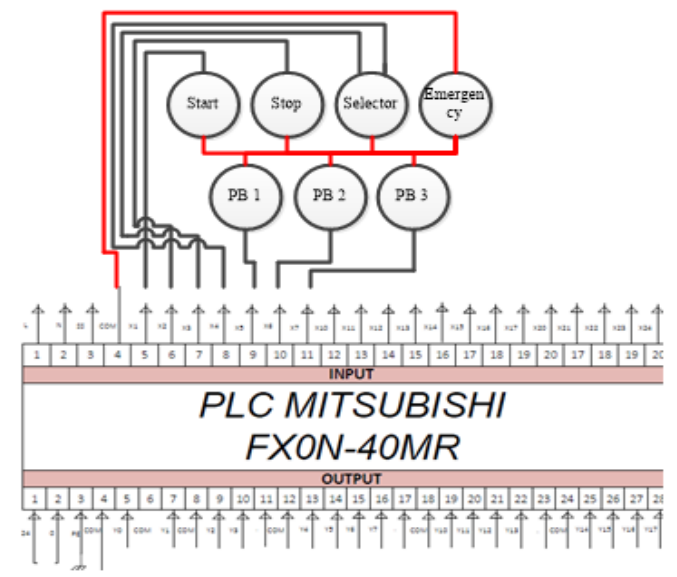

Gambar 7 Perancangan Push Button

Persamaan yang didapatkan untuk mengetahui gaya lagkah maju pada persamaan (1) dan mundur persamaan (2) seperti persamaan dibawah ini:

$$
\begin{gathered}
F=D^{2} \times \frac{\pi}{4} \times P \\
F=\left(D^{2}-d^{2}\right) \times \frac{\pi}{4} \times P
\end{gathered}
$$

Dimana:

$$
\begin{aligned}
& F=\text { Gaya Piston }(\mathrm{N}) \\
& \mathrm{D}=\operatorname{Diameter} \text { Piston }(\mathrm{m}) \\
& \mathrm{P}=\text { Tekanan Kerja }(\mathrm{Pa}) \\
& \mathrm{D}=\operatorname{Diameter} \text { Piston }(\mathrm{m})
\end{aligned}
$$

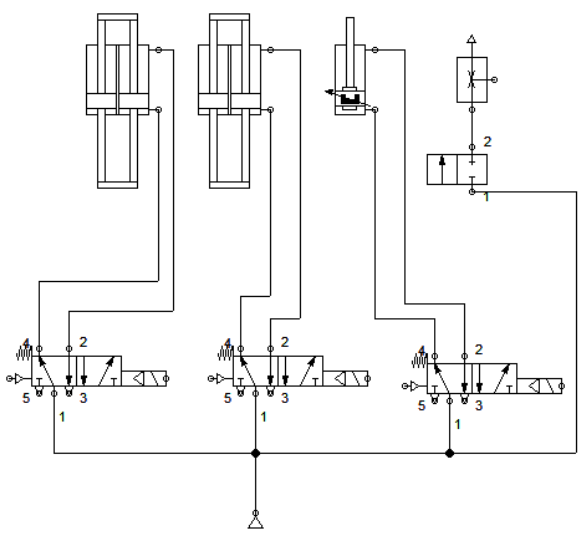

Gambar 8 Perancangan Pneumatik Mini Crane

\section{HASIL DAN PEMBAHASAN}

\section{A. Pengujian Sensor Proximity}

Pengujian jarak dilakukan untuk mengetahui berapa jarak pembacaan sensor proximity yang dibutuhkan untuk inisialisasi benda kerja. Untuk memulai kerja alat ini masukan berupa sensor proximity sebagai indikasi untuk alat bekerja.

TABEL II

PENGUJIAN SENSOR PROXIMITY

\begin{tabular}{cc}
\hline Jarak $(\mathrm{mm})$ & Keterangan \\
\hline 2 & Aktif \\
3 & Aktif \\
4 & Aktif \\
5 & Non aktif \\
\hline
\end{tabular}

Tabel II. menunjukan bahwa rentang jarak 2-4 mm benda dapat membaca sedangkan diatas $4 \mathrm{~mm}$ atau nilai $5 \mathrm{~mm}$ sensor proximity tidak dapat membaca. Range 2-4 $\mathrm{mm}$ alat dapat bekerja atau memenuhi tahapan-tahapan selanjutnya.

\section{B. Pengujian Tekanan Udara}

Pada gambar 9. Merupakan pengujian tekanan udara dilakukan untuk mengetahui apakah alat dapat bekerja dengan tekanan udara kecil dan mampu untuk mengangkat dan memindahkan benda kerja. Hasil dari pengujian terdapat pada

\begin{tabular}{|c|c|c|c|c|c|c|c|c|}
\hline \multirow{2}{*}{$\begin{array}{l}\text { Tekanan } \\
\text { (Bar) }\end{array}$} & \multirow{2}{*}{$\begin{array}{l}\text { Benda } \\
\text { kerja }\end{array}$} & \multicolumn{2}{|c|}{ Rodless 1} & \multicolumn{2}{|c|}{ Rodless 2} & \multicolumn{2}{|c|}{ Silinder } & \multirow{2}{*}{ Vacum } \\
\hline & & $U p$ & Down & $U p$ & Down & $U p$ & Down & \\
\hline 3 & Logam & $\sqrt{ }$ & $\sqrt{ }$ & $\sqrt{ }$ & $\sqrt{ }$ & $\sqrt{ }$ & $\sqrt{ }$ & $\sqrt{ }$ \\
\hline 4 & Logam & $\sqrt{ }$ & $\sqrt{ }$ & $\sqrt{ }$ & $\sqrt{ }$ & $\sqrt{ }$ & $\sqrt{ }$ & $\sqrt{ }$ \\
\hline 6 & Logam & $\sqrt{ }$ & $\sqrt{ }$ & $\sqrt{ }$ & $\sqrt{ }$ & $\sqrt{ }$ & $\sqrt{ }$ & $\sqrt{ }$ \\
\hline
\end{tabular}
tabel 3 .

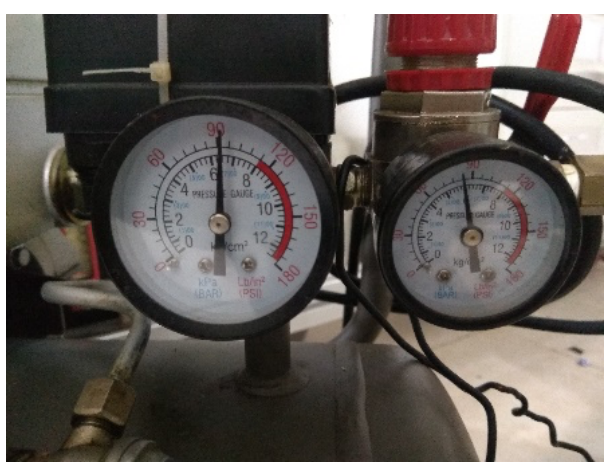

Gambar 9 Pengujian Tekanan Udara

TABEL III

PENGUJIAN TEKANAN UDARA

\section{Pengujian Pemindahan Barang}

Pada pengujian waktu dilakukan untuk mengetahui berapa waktu dalam satuan detik yang dibutuhkan untuk memindahkan benda kerja dari beberapa tempat. Pada pengujian ini dengan menggunakan teknan 3 bar, 4 bar dan 6 bar untuk seberapa pengaruhjnya hubungan tekanan yang diberikan dengan waktu yang didapatkan.

Pada Gambar 10. merupakan pengujian pemindahan barang. Dari titik awal menuju ke tempat membutuhkan jarak ang berbeda-beda. Terdapat 3 tempat yang dipindahkan dari titik awal, dengan menggunakan pengujian tekanan sebesar 3 bar, 4 bar dan 6 bar. Hasil menunjukan bahwa tempat ke 3 paling lama atau jarak yang ditempuh paling jauh. Tempat 2 dan tempat 1 dengan menggunakan tekanan yang berbeda-beda jarak yang ditempuh memiliki rata-rata yang sama. Gambar 10. menunjukan bahwa semakin besar tekanan yang diberikan maka semakin cepat waktu untuk pemindahan barang. Selain menentukan waktu pada penelitian ini juga menggunakan pengujian berat dengan memanfaatkan daya hisap.

\section{Pengujian Berat pada Tekanan}

Pada pengujian ini menggunkana tekanan dan berat untuk mengetahui berat yang dapat dibawa dengan tekanan yang 
ditentukan. Tekanan yang ditentukan sebesar 3 bar, 4 bar dan 6 bar. Setelah penentuan tekanan, berat benda diberikan bervariatif dari $150 \mathrm{~g}$ sampai $1050 \mathrm{~g}$. Tekanan yang diberikan oleh vacuum akan berpengaruh terhadap berat yang dibawa,

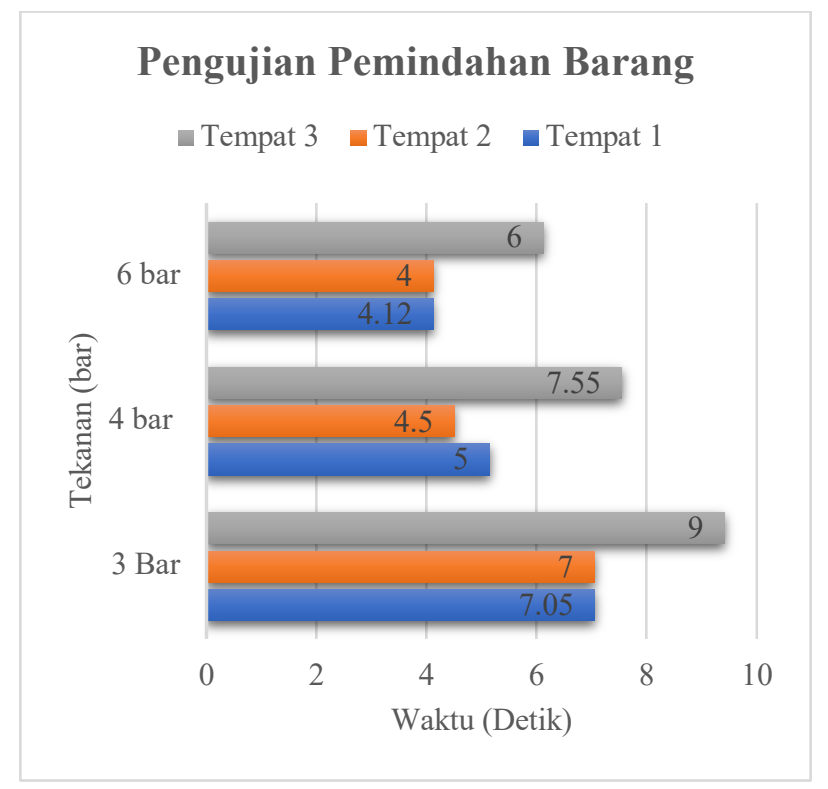

Gambar 10. Pengujian Pemindahan Barang

semakin tinggi tekanan yang diberikan maka semakin berat daya angkat berat maka semakin besar daya yang dikeluarkan oleh kompresor. Dari pernyataan disini maka kita akan bukti dengan pengujian yang sesuai dengan Gambar 11. yaitu sistem mini crane pembawa benda dengan berat yang bervariasi.

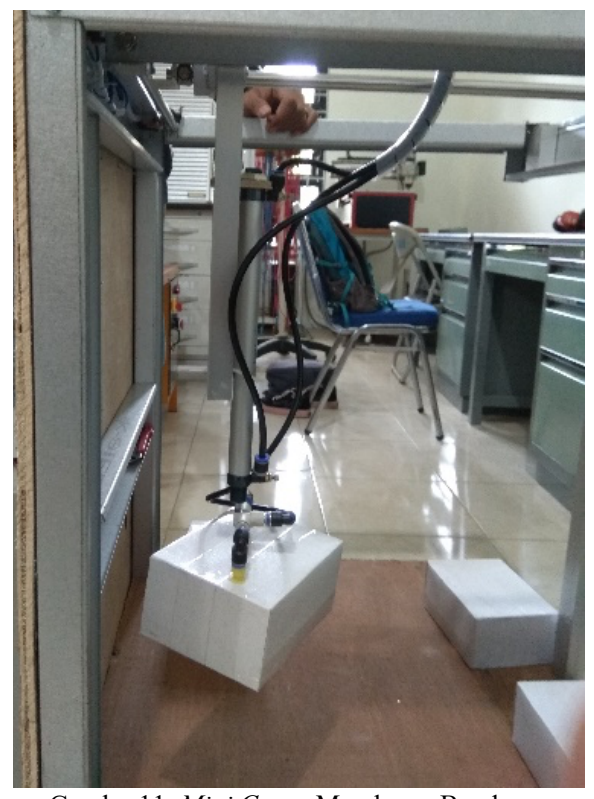

Gambar11. Mini Crane Membawa Benda

Berdasarkan hasil tabel IV menunjukan bahwa berat maksimal yang dapat dihisap vacuum pada tekanan 3 bar adalah $650 \mathrm{~g}$, pada tekanan 4 bar adalah $950 \mathrm{~g}$, dan pada tekanan
6 bar adalah 1050g. Pada sistem ini batas maksimal yaitu dengan seberat $1050 \mathrm{~g}$ dengan tekanan bar.

TABEL IV

PENGUJiAn BATAS Berat MAKSIMAL

\begin{tabular}{cl}
\hline Berat (gram) & Keterangan \\
\hline 150 & \\
250 & \\
450 & \\
550 & \\
650 & Batas 3 Bar \\
750 & \\
850 & \\
950 & Batas 4 Bar \\
1050 & Batas 6 Bar \\
\hline
\end{tabular}

\section{KESIMPULAN}

Berdasarkan hasil pengujian dan pembuatan prototype bahwa. Alat yang dibuat sesuai dengan fungsinya. Sensor yang digunakan untuk mendeteksi jenis material benda kerja menggunakan sensor proximity inductive. Sensor ini sangat akurat dalam mendeteksi jenis material benda kerja, sehingga tidak ada error dalam membedakan benda kerja berdasarkan jenis material. Jarak sensor proximity inductive dapat mendeteksi benda kerja dengan jarak kurang dari $4 \mathrm{~mm}$. Hasil menunjukan bahwa tempat ke 3 paling lama atau jarak yang ditempuh paling jauh. Tempat 2 dan tempat 1 dengan menggunakan tekanan yang berbeda-beda jarak yang ditempuh memiliki rata-rata yang sama, hal ini menunjukan bahwa semakin besar tekanan yang diberikan maka semakin cepat waktu untuk pemindahan barang. Berat maksimal yang dapat dihisap vacuum pada tekanan 3 bar adalah $650 \mathrm{~g}$, pada tekanan 4 bar adalah $950 \mathrm{~g}$, dan pada tekanan 6 bar adalah $1059 \mathrm{~g}$.

\section{REFERENSI}

[1] Anhar Khalid, H. R. (2016). Rancang bangun simulasi sistem pneumatik untuk pemindah. Jurnal intekna, Volume 16, 1-6.

[2] Syaprudin, D. (2018). Sortir Barang Berdasarkan Berat dan Tinggi Berbasis PLC dengan Monitoring. Prosiding Seminar Teknik Elektro Volume 3, 1-4.

[3] Ei Ei Cho, Z. M. (2014). Perancangan dan Implementasi Penggunaan Sistem Otomasi Crane Industri. Jurnal Internasional Teknik Ilmiah dan Riset Teknologi, Vol.03, Edisi.06, 1-9.

[4] Murie Dwiyaniti, C. H. (2018). Perancangan dan Implementasi PLC Hot Standby dan Scada Pada. Prosiding Seminar Nasional Teknik Elektro Volume 3, 17.

[5] Ahyar M, Z. A. (n.d.). Rancang bangun media praktikum sistem pneumatik. Prosiding Seminar Nasional, 1-10. 
[6] Ari Setiawan, S. S. (2004). Perancangan lengan robot pneumatik pemindah plat. Labratorium Teknik Kontrol Otomatik, 1-6.

[7] Samuel Yosia Dimpudus, D. E. (2015). Sistem Pengepakan Botol Minuman Kemasan Berbasis
Programmable Logic Controller. E-Journal Teknik Elektro dan Komputer vol. 4 no. 7, 1-8.

[8] Syufrijal, S. (2017). Aplikasi PLC Pada Crane Berbasis SCADA. AUTOCRACY: Jurnal Otomasi, Kendali, dan Aplikasi Industri, 4(02), 122-129. 